\title{
Targeted Deletion of a Cyclic Nucleotide-Gated Channel Subunit (OCNC1): Biochemical and Morphological Consequences in Adult Mice
}

\author{
Harriet Baker, ${ }^{1}$ Diana. M. Cummings, ${ }^{2}$ Steven D. Munger, ${ }^{3}$ Joyce W. Margolis, ${ }^{2}$ Linda Franzen, ${ }^{1}$ \\ Randall R. Reed, ${ }^{3}$ and Frank L. Margolis ${ }^{2}$ \\ ${ }^{1}$ Cornell University Medical College at The Burke Medical Research Institute, White Plains, New York 10605, 2 University of \\ Maryland School of Medicine, Baltimore, Maryland 21201, and ${ }^{3}$ The Howard Hughes Medical Institute and Department \\ of Molecular Biology and Genetics, Johns Hopkins Medical Institutes, Baltimore, Maryland 21205
}

The olfactory cyclic nucleotide-gated channel subunit 1 (OCNC1) is required for signal transduction in olfactory receptor cells. To further investigate the role of this channel in the olfactory system, the biochemical and morphological consequences of targeted disruption of OCNC1 were investigated in adult mice. Null as compared to wild-type mice had smaller olfactory bulbs, suggesting compromised development of the central target of the receptor cells. Ectopic olfactory marker protein (OMP)-stained fibers localized to the external plexiform layer reflected the relative immaturity of the olfactory bulb in the null mice. The olfactory epithelium of the knock-out mouse was thinner and showed lower expression of olfactory marker protein and growth-associated protein 43, indicating decreases in both generation and maturation of receptor cells. Tyrosine hydroxylase $(\mathrm{TH})$ expression in the olfactory bulb, examined as a reflection of afferent activity, was reduced in the majority of periglomerular neurons but retained in atypical or "necklace" glomeruli localized to posterior aspects of the olfactory bulb. Double label studies demonstrated that the remaining $\mathrm{TH}-$ immunostained neurons received their innervation from a subset of receptor cells previously shown to express a phosphodiesterase that differs from that found in most receptor cells. These data indicate that expression of OCNC1 is required for normal development of the olfactory epithelium and olfactory bulb. The robust expression of $\mathrm{TH}$ in some periglomerular cells in the OCNC1-null mice suggests that receptor cells innervating these glomeruli may use an alternate signal transduction pathway.

Key words: tyrosine hydroxylase; phosphodiesterase; olfactory marker protein; PAX6; atypical glomeruli; necklace glomeruli
The olfactory cyclic nucleotide-gated channel (OCNC), a nonselective cation channel, is an integral component of the signal transduction pathway in olfactory receptor neurons (Zufall et al., 1994; Zagotta and Siegelbaum, 1996; Wei et al., 1998). In olfactory transduction, a G-protein couples odorant-activated receptors to the elevation of intracellular cAMP levels through stimulation of adenylyl cyclase, leading to direct gating of the OCNC and initial depolarization of olfactory receptor neurons (Jones and Reed, 1989; Buck and Axel, 1991). Three channel subunits were shown to be expressed in the olfactory epithelium (OE): the relatively olfactory-specific OCNC1 and OCNC2 subunits, as well as an olfactory-specific splice variant of the rod photoreceptor $\beta$ subunit (Dhallan et al., 1990; Liman and Buck, 1994; Bradley et al., 1994; Sautter et al., 1998; Bönigk et al., 1999). OCNC1 forms functional homodimers in vitro (Dhallan et al., 1990) but in vivo is thought to be associated with either the $\beta$ subunit and/or OCNC2, each of which confers greater sensitivity to cyclic nucleotides and changes in single-channel kinetics (Bradley et al., 1994; Liman and Buck, 1994; Sautter et al., 1998; Bönigk et al., 1999).

\footnotetext{
Received June 1, 1999; revised Aug. 11, 1999; accepted Aug. 16, 1999.

This work was supported by National Institutes of Health Grants AG09686 (H.B.) and DC03112 (F.M.), and by Howard Hughes Medical Institute (R.R.).

Correspondence should be addressed to Dr. Harriet Baker, Cornell University Medical College at The Burke Medical Research Institute, 785 Mamaroneck Avenue, White Plains, NY 10605. E-mail: habaker@med.cornell.edu.

Copyright (C) 1999 Society for Neuroscience 0270-6474/99/199313-09\$05.00/0
}

A recent study reported that neonatal mice deficient in OCNC1 were anosmic (Brunet et al., 1996) and died within a few days after birth, although methods were recently developed to promote their survival (Parent et al., 1998). These mice exhibited no EOG responses to odorants previously shown to increase synthesis of either cAMP or IP3 (Boekhoff et al., 1990; Breer et al., 1990) or to complex odorants such as urine, suggesting a lack of sensitivity to all odors. Because the EOG is a cell population measure, responses might not have been detected that are mediated through transduction pathways expressed only in a subpopulation of receptor neurons.

Our laboratories addressed this issue by examining afferent neuron activity-dependent regulation of tyrosine hydroxylase (TH) expression in the olfactory bulb. TH expression in intrinsic periglomerular neurons shows profound downregulation after either deafferentation or naris closure and upregulation after reafferentation (Nadi et al., 1981; Kawano and Margolis, 1982; Baker et al., 1983, 1993; Kosaka et al., 1987; Cho et al., 1996). These observations indicate that bulbar $\mathrm{TH}$ expression reflects afferent stimulation of the olfactory bulb.

Recently, receptor neurons were characterized (Juilfs et al., 1997) that are localized to the posterior recesses of the OE and project to a small group of atypical, modified, or "necklace" glomeruli found in posterior aspects of the olfactory bulb (Greer et al., 1982; Pedersen et al., 1986; Zheng et al., 1987; Shinoda et al., 1989, 1990; Ring et al., 1997). These receptor neurons express both a specific guanylyl cyclase (GC-D) and a cyclic GMP- 
stimulated phosphodiesterase, PDE2 (Juilfs et al., 1997). The presence of PDE2 and GC-D in a specific subset of receptor neurons and their unique projection patterns suggests that a second cyclic nucleotide-mediated transduction pathway may be active in the OE. If this second pathway is functioning in OCNC1-null mice then its activity should also be evidenced by alterations in activity-based measures of gene expression in the olfactory bulb.

The current studies used a line of OCNC1-null mice generated in our laboratory that survived to adulthood (Parent et al., 1998). All glomeruli in wild-type mice exhibited extensive $\mathrm{TH}$ immunoreactivity. In null mice, many TH-immunostained cells were found in necklace glomeruli, but few in other glomeruli, suggesting that necklace glomeruli receive input from receptor neurons that use an alternate signal transduction pathway, independent of the cAMP-activated OCNC1 channel. Differences in olfactory bulb and epithelial morphology also indicated that loss of OCNC1 and resultant long-term odor deprivation compromised normal development of the olfactory system.

\section{MATERIALS AND METHODS}

Animals. Wild-type (male and female) and hemizygous OCNC1-null (male) mice on a 129/svImJ $\times$ C57Bl/6J background (Parent et al., 1998) were raised to adulthood in our laboratories. This line, developed in our laboratory, also produces the high level of neonatal lethality reported by Brunet et al. (1996). This property can be overcome by reduction of litter size within the first $24 \mathrm{hr}$ after birth. Presumably, by reducing competition between null pups and their littermates, sufficient time to suckle promotes viability. For immunocytochemical procedures, six mice of similar body weight and of each genotype at $6-8$ weeks of age were deeply anesthetized with ketamine-xylazine $(3: 1 ; 100 \mathrm{mg} / \mathrm{kg}$ body weight: $33 \mathrm{mg} / \mathrm{kg}$ body weight). Mice were perfused transcardially with saline containing $0.5 \%$ sodium nitrite followed by either (1) $4 \%$ paraformaldehyde (PFA; $\mathrm{pH} 7.4$ ) for immunohistochemical processing of olfactory bulbs or (2) PLP fixative ( $2 \%$ paraformaldehyde, $0.75 \mathrm{M}$ lysine, and $0.2 \%$ sodium periodate in $50 \mathrm{~mm}$ phosphate buffer, $\mathrm{pH}$ 7.4) for processing of olfactory mucosae. Nasal cavities were post-fixed in PLP fixative overnight at $4^{\circ} \mathrm{C}$. Olfactory bulbs from mice perfused with $4 \%$ PFA were post-fixed at room temperature for $2 \mathrm{hr}$ and stored in $0.1 \mathrm{M}$ phosphate buffer, $\mathrm{pH} 7.4$, at $4^{\circ} \mathrm{C}$ until immunohistochemical processing. After post-fixation, brains were cryoprotected in $30 \%$ sucrose, and $40 \mu \mathrm{m}$ horizontal sections were prepared on a sliding microtome. Epithelia were decalcified, embedded in paraffin, and $6-8 \mu \mathrm{m}$ sections were obtained on a rotary microtome.

For measurement of TH activity and olfactory marker protein (OMP) levels, animals were killed by cervical dislocation and thoracotomy. Olfactory bulbs were dissected, frozen on dry ice, weighed, and stored at $-80^{\circ} \mathrm{C}$ until processed. Mice were genotyped by PCR of tail tip DNA as previously described (Parent et al., 1998). All procedures were performed under protocols approved by the Institutional Animal Care and Use Committees of Johns Hopkins, Cornell University, and the University of Maryland and conformed to National Institutes of Health guidelines.

Immunocytochemistry. Floating sections of olfactory bulb were processed by previously published methods (Baker et al., 1993). Briefly, sections were first blocked with $1 \%$ bovine serum albumin (BSA) in 0.1 M PBS and incubated with the following antisera: rabbit anti-TH (1: 25,000; from T. H. Joh, Cornell University Medical College, White Plains, NY), goat anti-OMP (1:35,000; prepared in our laboratory) (Keller and Margolis, 1975), rabbit anti-Pax6 (1:1500; against the 17 C-terminal amino acids of the mouse protein; prepared in our laboratory), and sheep anti-cFos (1: 7000; antipeptide; Genosys, The Woodlands, TX). For olfactory bulb staining, tissue was washed and incubated with the appropriate biotinylated secondary antibodies obtained from Vector Laboratories (Burlingame, CA). After incubation with the Vector Elite $\mathrm{ABC}$ kit, antigens were detected with 3,3' diaminobenzidine tetrahydrochloride (DAB) as the chromogen. For double-labeling, sections previously stained for TH $(1: 25,000)$ using DAB were incubated overnight with a chicken antiserum specific for phosphodiesterase 2 (1:1500; PDE2,
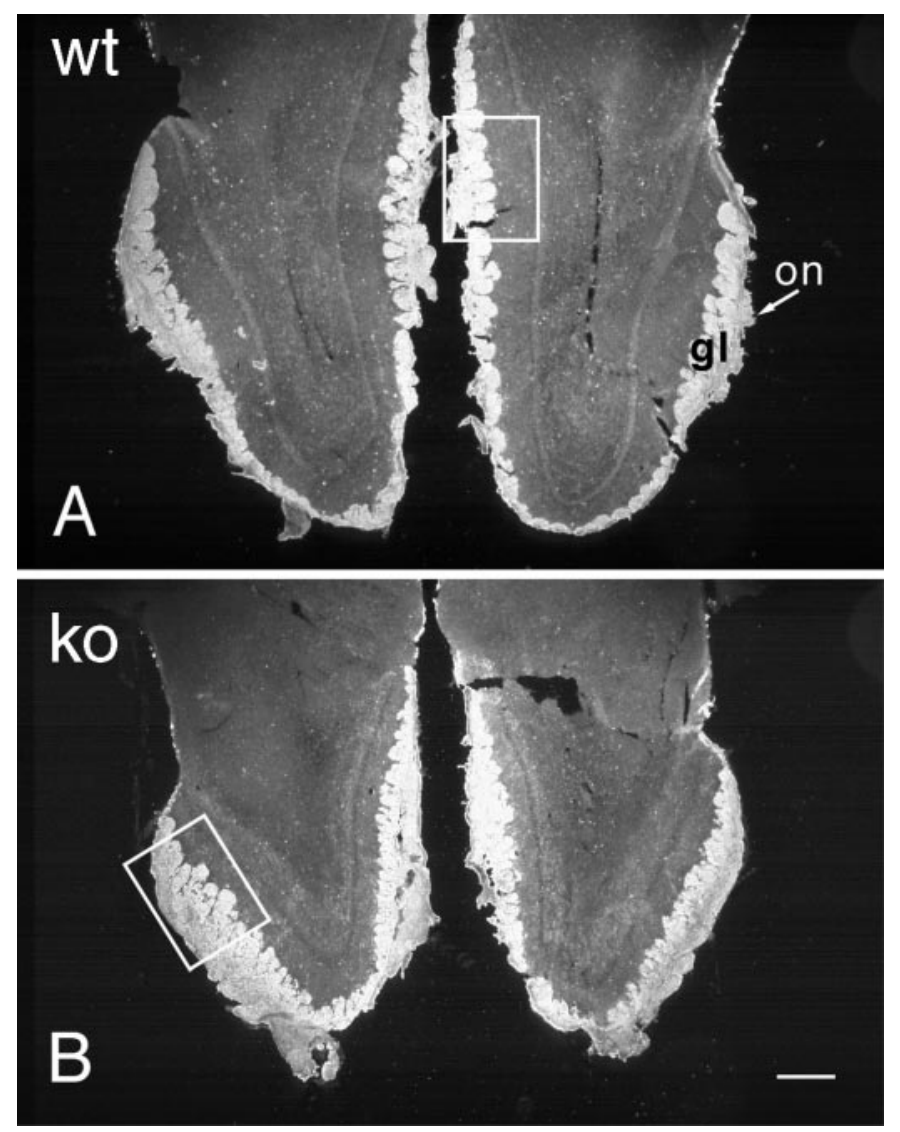

Figure 1. OMP immunostaining in horizontal sections of olfactory bulbs from adult wild-type $(A, w t)$ and OCNC1-null $(B, k o)$ mice illustrated in dark-field photomicrographs. Note the smaller size of the olfactory bulbs in the null mice, but the apparently normal OMP staining of the olfactory nerve (on) and glomerular $(g l)$ layers. Boxes indicate regions shown at higher magnification in Figure 2. Scale bar, $200 \mu \mathrm{m}$.

kindly provided by Dr. J. Beavo, University of Washington) followed by a biotinylated donkey anti-chicken secondary antiserum (Jackson ImmunoResearch Laboratories, West Grove, PA) and the ABC kit using Vector blue as the chromogen.

For the olfactory epithelial staining, the nasal cavities from animals perfused with PLP fixative were dehydrated in graded ethanols, cleared in toluene, embedded in paraffin, and sectioned coronally at $6-8 \mu \mathrm{m}$. Every 100th section was mounted onto Superfrost Plus slides (Fisher Scientific, Pittsburgh, PA) and incubated in a $60^{\circ} \mathrm{C}$ oven for $2 \mathrm{hr}$. Sections were deparaffinized, rehydrated in graded alcohols, and processed for immunohistochemistry for OMP or growth-associated protein 43 (GAP43). Briefly, sections were incubated in Tris phosphate buffer (TBS), pH 7.2, containing $0.1 \%$ gelatin and $0.2 \%$ Triton X-100, rinsed, and transferred to TBS with $3 \%$ normal rabbit serum to block nonspecific binding. Afterwards, sections were incubated in either goat anti-OMP (1: $5000)$ or mouse anti-GAP43 (1:100; Boehringer Mannheim, Indianapolis, IN) overnight at room temperature. The next day, slides were rinsed, transferred to the appropriate biotinylated secondary antisera (Vector Laboratories; dilution: 1:200), rinsed, and incubated in avidin biotin complex (ABC; Vector Laboratories). Reaction products were visualized by treating sections with DAB $(0.15 \mathrm{mg} / \mathrm{ml})$ in the presence of $\mathrm{H}_{2} \mathrm{O}_{2}$. Slides were then rinsed, dehydrated through graded ethanols, cleared in xylenes, and coverslipped using DPX mounting medium (Aldrich, Milwaukee, WI).

Epithelial thickness. Sections adjacent to those processed for immunohistochemistry were stained with hematoxylin and eosin. Coronal sections of the epithelia of wild-type and knock-out mice were traced at $640 \times$ magnification using a Nikon Optiphot microscope fitted with a camera lucida drawing tube. On both the left and right sides of the nasal cavity in three representative sections separated by $600 \mu \mathrm{m}$, measurements of epithelial thickness were made at two points along the nasal 
Table 1. Laminar width and bulb length in wild-type and null OCNC-1 mice

\begin{tabular}{|c|c|c|c|c|}
\hline Genotype & Glomerular layer & External plexiform layer & Granule cell layer & Bulb length \\
\hline Wild type $(\mathrm{wt})^{a}$ & $185.2 \pm 9.92$ & $227.9 \pm 7.69$ & $892 \pm 47$ & $3,266 \pm 36$ \\
\hline Null (n) & $134.8 \pm 9.90^{*}$ & $125.2 \pm 11.70^{*}$ & $690 \pm 31^{*}$ & $2,340 \pm 272 *$ \\
\hline $\mathrm{n} / \mathrm{wt}$ & 0.73 & 0.55 & 0.77 & 0.72 \\
\hline
\end{tabular}

${ }^{a}$ Data are presented as mean micrometers $\pm \mathrm{SE} ; n=3$.

*Indicates significant differences between wild-type and null mice, $p<0.05$.

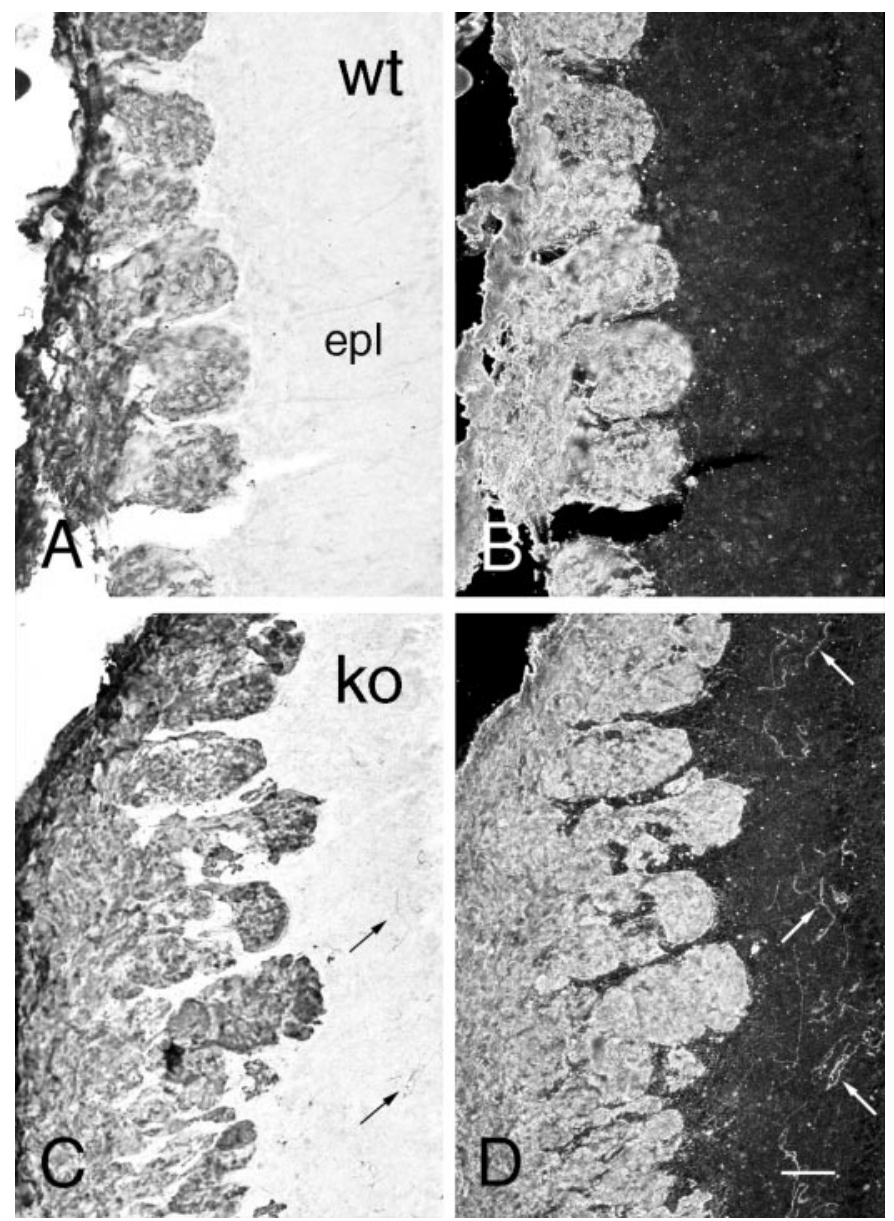

Figure 2. Bright-field $(A, C)$ and dark-field $(B, D)$ photomicrographs illustrating the presence of ectopic OMP-immunolabeled fibers in OCNC1-null $(C, D ; k o)$ and not in wild-type $(A, B, w t)$ mouse olfactory bulbs. Fibers (arrows) are scattered throughout the external plexiform layer $(e p l)$ of the null mice. Scale bar, $40 \mu \mathrm{m}$.

septum using a computer-controlled digitizing tablet and Sigma Scan computer software (Jandel Scientific, Corte Madera, CA). At each point, the thickness of the epithelium was measured from the luminal surface to the basal lamina. The two measurements along each side of the septum were not substantially different; therefore they were averaged. In addition, the mean thickness measurements from the left and right sides of the septum were averaged for each of the three sections measured per animal ( $n=3$ per genotype).

Olfactory bulb size. Using an eyepiece micrometer, the widths of the glomerular, external plexiform, and granule cell layers as well as the length of the olfactory bulb were measured in TH-stained sections from three wild-type and three knock-out mice. Five sections, spanning the dorsoventral aspects of the olfactory bulb, were assessed for each mouse $(n=3$ per genotype).

Biochemistry. Individual bulbs were homogenized in $250 \mu \mathrm{l}$ PBS (in mM: $137 \mathrm{NaCl}, 2.7 \mathrm{KCl}, 10 \mathrm{NaH}_{2} \mathrm{PO}_{4}$, and $\left.1.7 \mathrm{KH}_{2} \mathrm{PO}_{4}, \mathrm{pH} 7.4\right)$. The substantia nigra and caudate nucleus were homogenized in $450 \mu \mathrm{l}$ PBS.

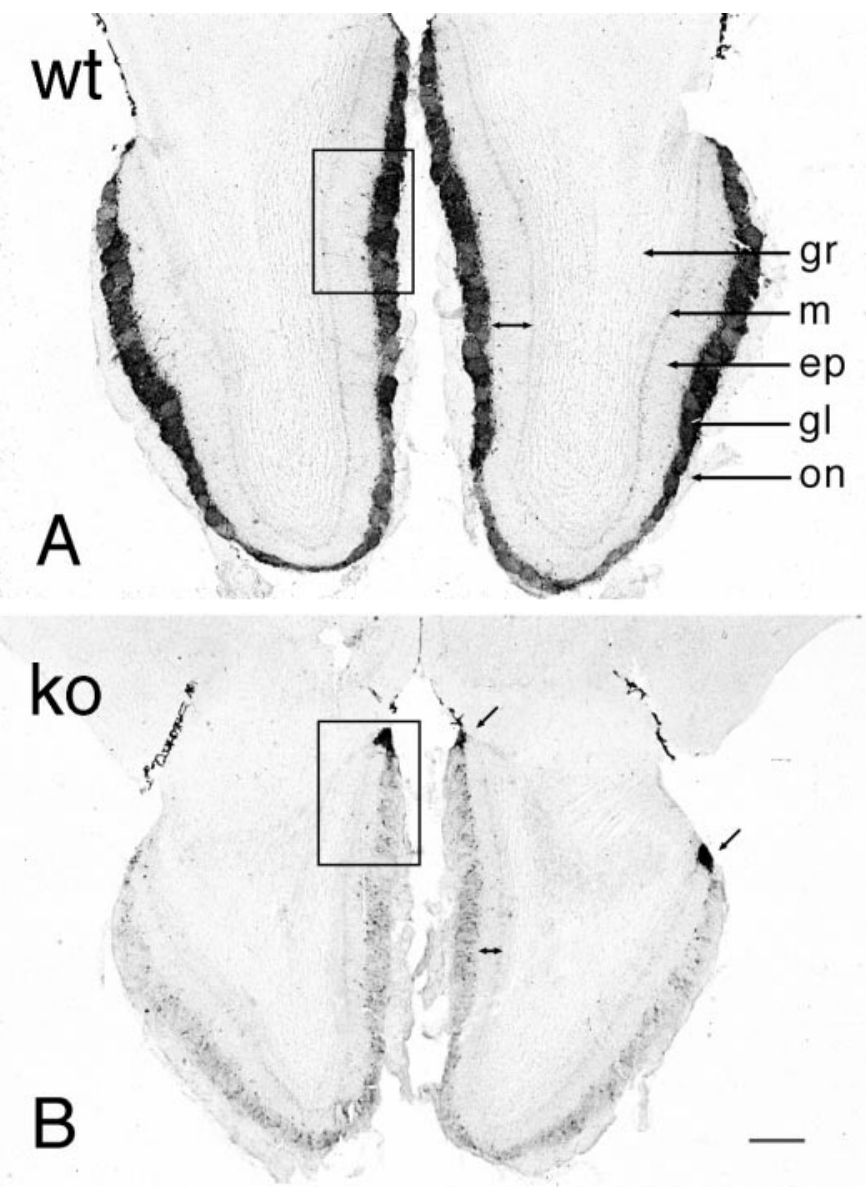

Figure 3. Bright-field photomicrographs of TH immunostaining in wildtype $(A, w t)$ and OCNC1-null $(B, k o)$ mice. In wild-type mice, TH staining occurs in periglomerular cells surrounding all glomeruli and in fibers within the glomeruli. In the null mice, the majority of glomeruli have only a few TH-labeled neurons and display a dramatic reduction in fiber staining within the glomeruli. However, normal TH staining is found in a group of glomeruli (arrows) on posterior aspects of the olfactory bulb. Double arrows indicate the decrease in width of the external plexiform layer in OCNC1-null mice. $e p$, External plexiform layer; $g l$, glomerular layer; $g r$, granule cell layer; $m$, mitral cell layer; $o n$, olfactory nerve layer. Boxes indicate regions shown at higher magnification in Figure 4. Scale bar, $200 \mu \mathrm{m}$.

Aliquots of homogenates were taken for determination of TH activity by the method of Joh et al. (1973). OMP was measured by an ELISA assay as follows. Aliquots of each homogenate were adjusted to a final concentration of $0.1 \%$ Triton X-100 and $0.1 \%$ sodium azide, kept on ice for $10 \mathrm{~min}$, and then centrifuged for $15 \mathrm{~min}$ at $16,000 \times g$ at $4^{\circ} \mathrm{C}$. Protein content of the supernatants was determined by the Bradford method (Bio-Rad, Hercules, CA) using bovine serum albumin as a standard, and the samples were then stored at $-80^{\circ} \mathrm{C}$. For determination of OMP content, samples were thawed on ice, and aliquots were diluted 1:1000 in BBS (17 mM NaB $\mathrm{ma}_{7} \cdot \mathrm{H}_{2} \mathrm{O}$ and $120 \mathrm{~mm} \mathrm{NaCl}, \mathrm{pH}$ 8.5). Assays were performed in freshly purchased, 96 well Immulon $2 \mathrm{HB}$, U-bottom 


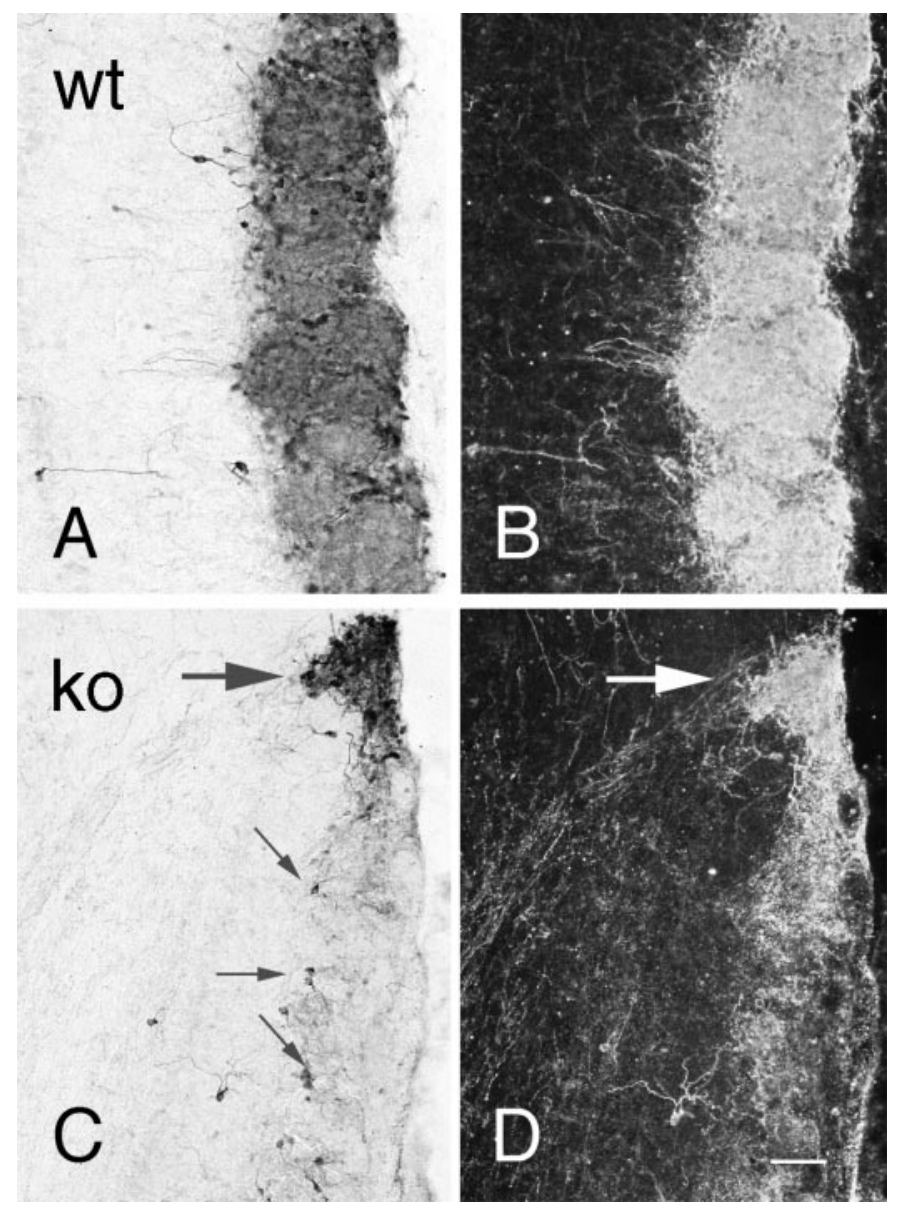

Figure 4. Bright-field $(A, C)$ and dark-field $(B, D)$ photomicrographs of TH immunostaining of olfactory bulb in wild-type $(A, B ; w t)$ and OCNC1-null $(C, D ; k o)$ mice. In wild-type mice, strong staining is observed in periglomerular cells and glomerular processes of all glomeruli. In the null mice, only scattered periglomerular cells (small arrows) contain TH in most glomeruli and, as illustrated in dark-field $(D)$, labeled processes are absent. In contrast, TH staining is normal in both cells and processes in the atypical or necklace glomeruli (large arrow). Scale bar, $40 \mu \mathrm{m}$.

ELISA plates (Dynex Technologies, Chantilly, VA). To wells containing $200 \mu \mathrm{l}$ of BBS, 10-20 $\mu \mathrm{l}$ aliquots of diluted extracts were added to contain $\sim 250 \mathrm{pg}$ of OMP per well. A standard curve of OMP in the range of 50-500 pg was included on each plate. The standard OMP solution (10 $\mathrm{pg} / \mu \mathrm{l}$ of OMP) was prepared daily. Samples and standards were all run in triplicate. Each plate also contained several controls, i.e., OMP with no antibody, OMP with only primary antibody, and OMP with only secondary antibody. After vibration mixing of sample and buffer, the plates were covered and incubated at $37^{\circ} \mathrm{C}$ for $2 \mathrm{hr}$. The plates were washed three times with TBS (in mM: 25 Tris, $137 \mathrm{NaCl}$, and $2.7 \mathrm{KCl}$ adjusted to $\mathrm{pH} 7.4$ with $\mathrm{HCl}$ ).

Unreacted sites on the plates were blocked by incubation with 220 $\mu \mathrm{l} /$ well of $1 \%$ normal goat serum in dilution buffer (1\% bovine serum albumin, $0.1 \%$ sodium azide, and $0.5 \%$ Tween- 20 in TBS) at $37^{\circ} \mathrm{C}$ for 30 min. The blocking solution was removed and replaced with $200 \mu \mathrm{l}$ of rabbit anti-OMP diluted 1:2000 in dilution buffer. The covered plates were incubated at room temperature overnight and then washed five times with TBS. Goat anti-rabbit-alkaline phosphatase (Sigma, St. Louis, MO) diluted 1:5000 in dilution buffer was added $(200 \mu \mathrm{l} /$ well $)$ and incubated at $37^{\circ} \mathrm{C}$ for $2 \mathrm{hr}$ followed by five washes with TBS. To quantify the phosphatase activity, $150 \mu \mathrm{l}$ of freshly prepared $p$-nitrophenyl phosphate (Sigma 104) at $2 \mathrm{mg} / \mathrm{ml}$ in assay buffer (10\% diethanolamine, $0.02 \%$ sodium azide, and $1 \mathrm{~mm} \mathrm{MgCl}_{2}, \mathrm{pH} 9.8$ ) was added to each well. The increase in absorption at $405 \mathrm{~nm}$ was monitored as a function of time at room temperature, on a Dynatech (Chantilly, VA) MRX microplate reader. OMP content was determined by comparison to the standard curve on the same plate.

Statistical analysis. Data were analyzed by either unpaired or paired Student's $t$ test with significance set at $p<0.05$.

\section{RESULTS}

\section{Morphology and innervation of the olfactory bulb in OCNC1-null and control mice}

The most distinguishing characteristic of the OCNC1-null mice was the smaller size of the olfactory bulb (Fig. 1, compare $A, B$ ). In null mice all laminae were narrower with the biggest differences observed in the external plexiform layer (Table 1), which was $55 \%$ of the thickness of that of wild-type mice. The thickness of the glomerular and granule cell layers also were smaller as was the length of the olfactory bulb. The protein content of bulbs from null mice was $53 \%$ of wild-type (mean $\mathrm{mg} / \mathrm{bulb} \pm \mathrm{SE}$; $0.67 \pm 0.03$ vs $1.26 \pm 0.05$, respectively; $p<0.05 ; n=3-10$ ).

To assess afferent innervation, olfactory bulbs were stained for OMP. Nerve fiber and glomerular staining were normal both in distribution and intensity in the null mice (Fig. 1). However, aberrant fiber staining, reminiscent of that found during normal development (Monti Graziadei et al., 1980; Baker and Farbman, 1993; Gong and Shipley, 1995), was observed in the external plexiform layer (Fig. 2). The fibers were more disorganized than in developing control mice. Lower levels of OMP, measured by ELISA (Mean percentage decrease \pm SE, $64 \pm 3.0 \%$ ), paralleled the smaller size of the olfactory bulb in the OCNC-1-null mice.
Figure 5. TH activity in the olfactory bulb $(O B)$, substantia nigra $(S N)$, and caudate nucleus $(C N)$ of wild-type $(w t)$ and OCNC1-null (ko) mice. In the null mice, TH activity is normal in $\mathrm{SN}$ and $\mathrm{CN}$, but lower only in the olfactory bulb. Student's unpaired $t$ test; * $p<0.01 ; n=3-10$.

\section{A}

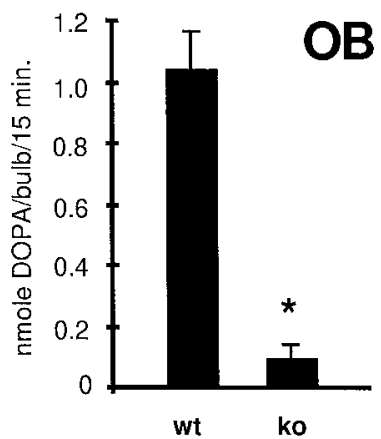

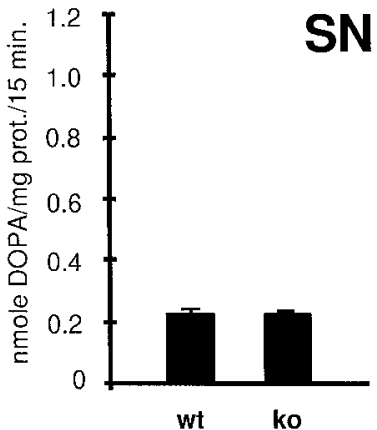

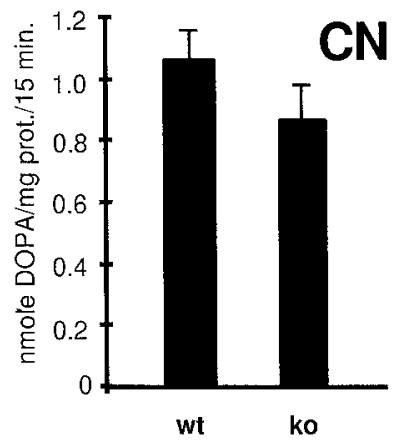




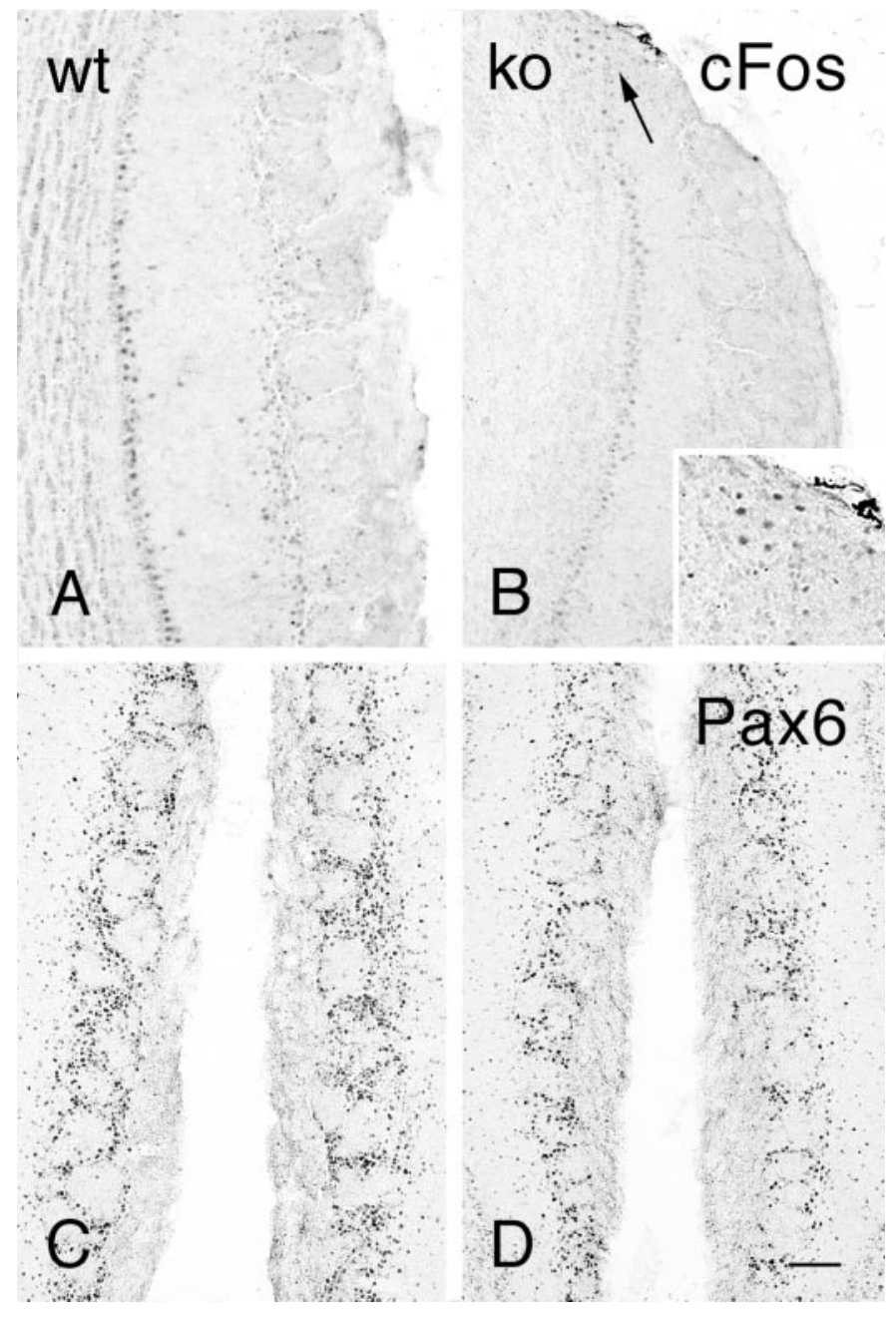

Figure 6. Bright-field photomicrographs illustrating $\mathrm{cFos}(A, B)$ and Pax6 $(C, D)$ immunostaining in the olfactory bulbs of wild-type $(A, C ; w t)$ and OCNC1-null $(B, D ; k o)$ mice. In null mice, $\mathrm{cFos}$ is absent in most glomeruli but staining is present in the region of the necklace glomeruli (arrow, inset). Pax6 immunostaining is present in the olfactory bulbs of both wt and ko mice. Scale bar: $A-D, 120 \mu \mathrm{m}$; inset, $60 \mu \mathrm{m}$.

These results suggested that fewer olfactory receptor cells are innervating the olfactory bulb (see below).

\section{Tyrosine hydroxylase staining and activity in the olfactory bulb}

TH immunostaining was dramatically less in the majority of glomeruli in the null olfactory bulb (Fig. 3) and was similar to that previously observed in odor-deprived mice (Baker et al., 1993). In most regions the reduction was uniform with only scattered cells and few intraglomerular fibers retaining TH immunoreactivity. In contrast, a group of glomeruli in the posterior aspects of the olfactory bulb, variously called either necklace or atypical glomeruli and including the modified glomerular complex, retained strong TH staining in both cells and fibers (Fig. 4).

In confirmation of the immunocytochemical findings, $\mathrm{TH}$ activity in bulbs of OCNC1-null mice was $10 \%$ of wild-type levels (Fig. $5 A$ ). The effect was specific to the olfactory bulbs since $\mathrm{TH}$ activity did not differ between wild-type and null mice in either the substantia nigra or the caudate nucleus, the former containing
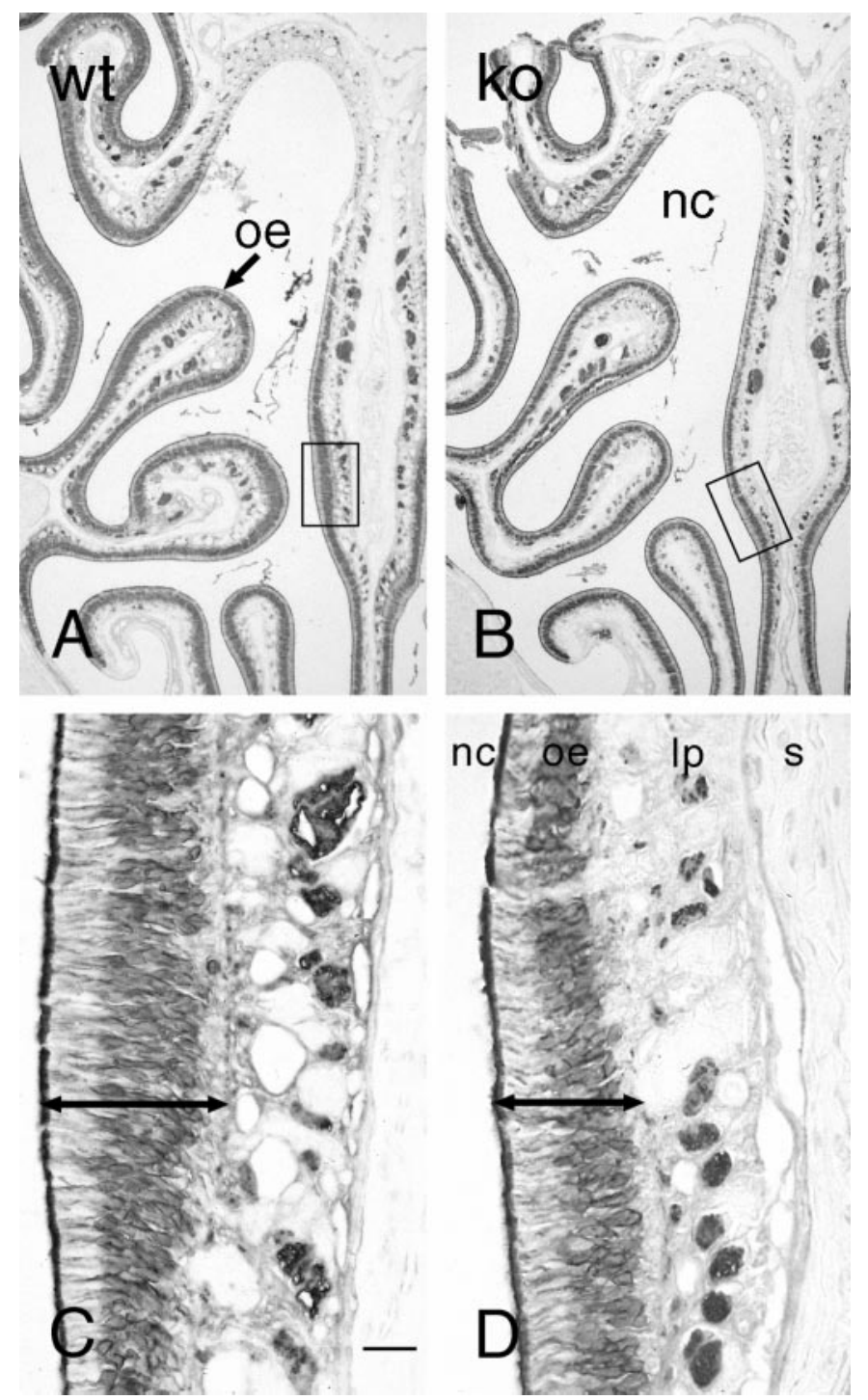

Figure 7. OMP immunostaining in the olfactory epithelium of wild-type $(A, C ; w t)$ and OCNC1-null $(B, D ; k o)$ mice. Low-power micrographs $(A$, $B$ ) illustrate that the receptor epithelium (oe) is thinner ( $C, D$, compare length of double arrows) in all regions of the nasal cavity $(n c)$. The boxed areas in $A$ and $B$ are shown at higher magnification in $C$ and $D$. $l p$, Lamina propria; $s$, nasal septum. Scale bar: $A, B, 250 \mu \mathrm{m} ; C, D, 30 \mu \mathrm{m}$.

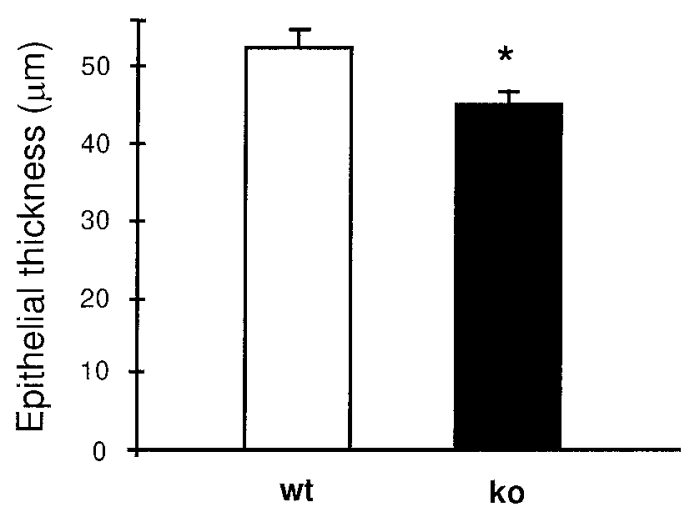

Figure 8. Bar graph illustrating that the septal receptor epithelium is $15 \%$ thinner in OCNC1-null mice $(k o)$ as compared to wild-type mice (wt). $n=3$ per group. ${ }^{*} p<0.05$ by paired Student's $t$ test. 
Figure 9. GAP43 immunostaining in the olfactory epithelium of wild-type $(A, w t)$ and OCNC1-null $(B, k o)$ mice. Fewer neurons (small arrows) are stained with GAP43, indicating that the number of both mature and immature neurons is lower in the null mice. The double arrows indicate the difference in the thickness of the olfactory epithelium (oe). $l p$, Lamina propria; $n c$, nasal cavity; $s$, septum. Scale bar, $30 \mu \mathrm{m}$.
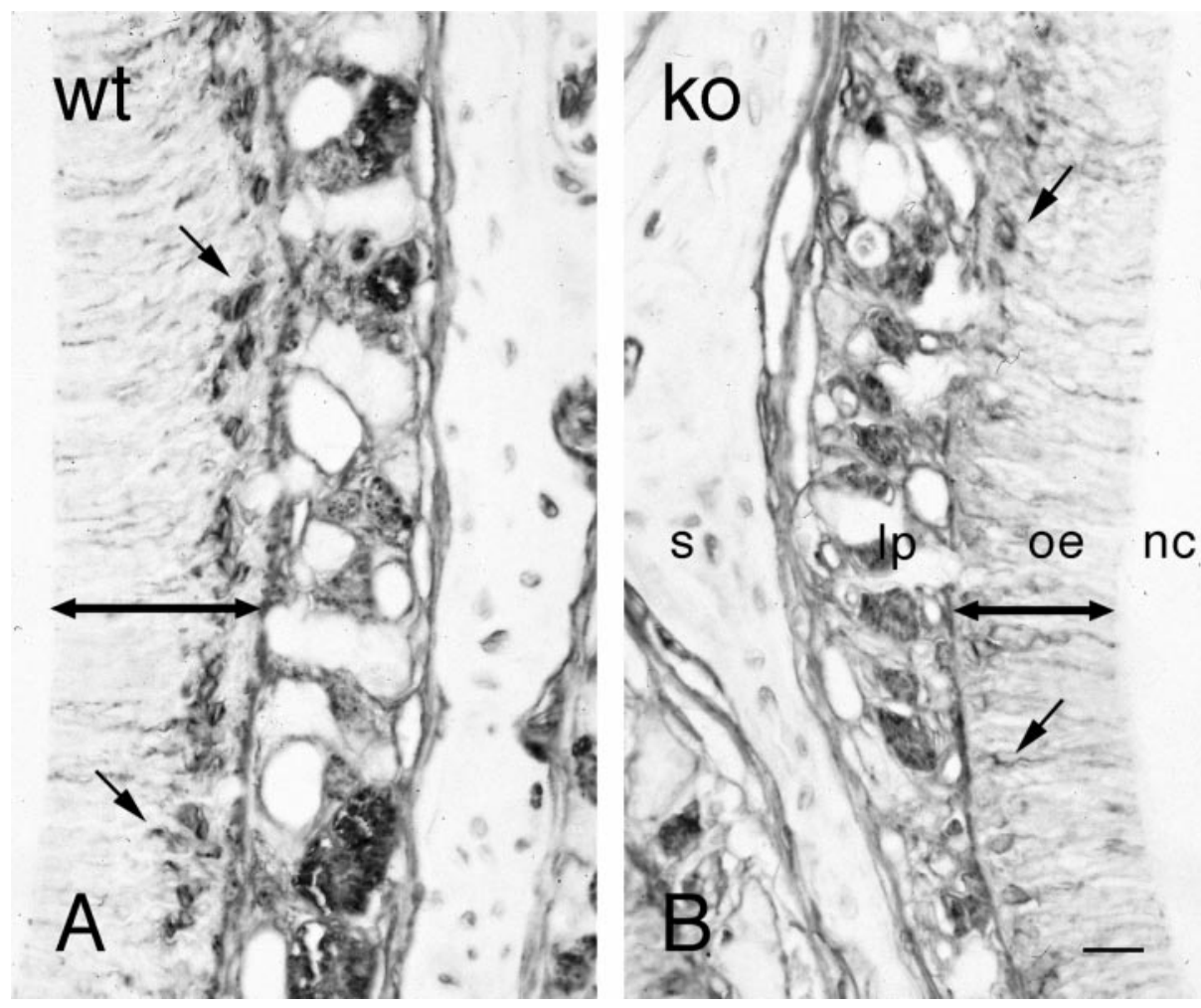

dopaminergic cell bodies that terminate in the latter brain region (Fig. 5B,C).

\section{cFos and PAX6 immunoreactivity in the olfactory bulb}

Previous studies demonstrated that expression of the immediate early gene cfos and its product, cFos, were reduced in parallel with TH expression (Guthrie and Gall, 1995; Jin et al., 1996). In the current study, cFos immunostaining was much less intense in null mice (Fig. 6B) compared to wild-type mice (Fig. 6A), except in the region of the necklace glomeruli where staining was similar to that seen in controls. PAX6 immunoreactivity was of normal intensity in both the granule cell and glomerular layers in null mice (Fig. 6C,D), suggesting that migration from the subependymal zone through the rostral migratory stream occurred in these mice (Dellovade et al., 1997).

\section{OMP and GAP43 staining in the olfactory epithelium}

Although the olfactory epithelium appeared structurally normal, the OE was thinner in OCNC1-null mice (Fig. 7). In addition, the number of OMP-labeled cells, assessed by the width of the stained area (Fig. 8), also was smaller. There also appeared to be fewer GAP43 immunostained immature neurons (Fig. 9). Taken together, these observations indicate that there are alterations in the genesis and maturation of olfactory neurons in the $\mathrm{OE}$ of the OCNC1-null mice, leading to a reduction in maturation and development of the olfactory bulb.

\section{Double immunolabeling with TH and PDE in olfactory bulb}

To demonstrate that the TH-immunostained cells were necklace glomeruli, double label experiments were performed with a PDE antiserum that recognizes PDE2, the PDE subtype found only in atypical glomeruli (Juilfs et al., 1997). With the exception of scattered fibers in other regions of the olfactory bulb, PDE immunoreactivity in the null mice was limited to fibers innervating glomeruli heavily stained with TH (Fig. 10).

\section{DISCUSSION}

These studies demonstrate that expression of the cyclic nucleotide-gated channel 1 subunit (OCNC1) is required for normal development of the olfactory epithelium and olfactory bulb. The ability of these null mice to survive to adulthood suggested that either the olfactory system is not necessary for suckling behavior or that some olfactory neurons express other transduction pathways that process sufficient odor information to allow for nipple attachment (Juilfs et al., 1997; but see Gold, 1999).

Loss of OCNC1 significantly altered several aspects of olfactory system development. Most apparent was the smaller size of the olfactory bulb that was evident on visual inspection and confirmed by total protein measurements. All laminae were reduced in width, suggesting loss of processes, especially in the external plexiform layer, and neurons in the granule and periglomerular layers. Whether the number of mitral cells is fewer remains to be assessed. The smaller olfactory bulb observed in the OCNC1-null mice is similar to that seen after both neonatal and adult odor deprivation (Frazier and Brunjes, 1988; Baker, 1990; Baker et al., 1993), suggesting that similar activitydependent mechanisms may regulate neuronal maturation and survival in the olfactory bulb of the OCNC1-null and of odordeprived mice.

A reduction in bulb size could result from a change in rate or number of cells destined to be granule and periglomerular cells 

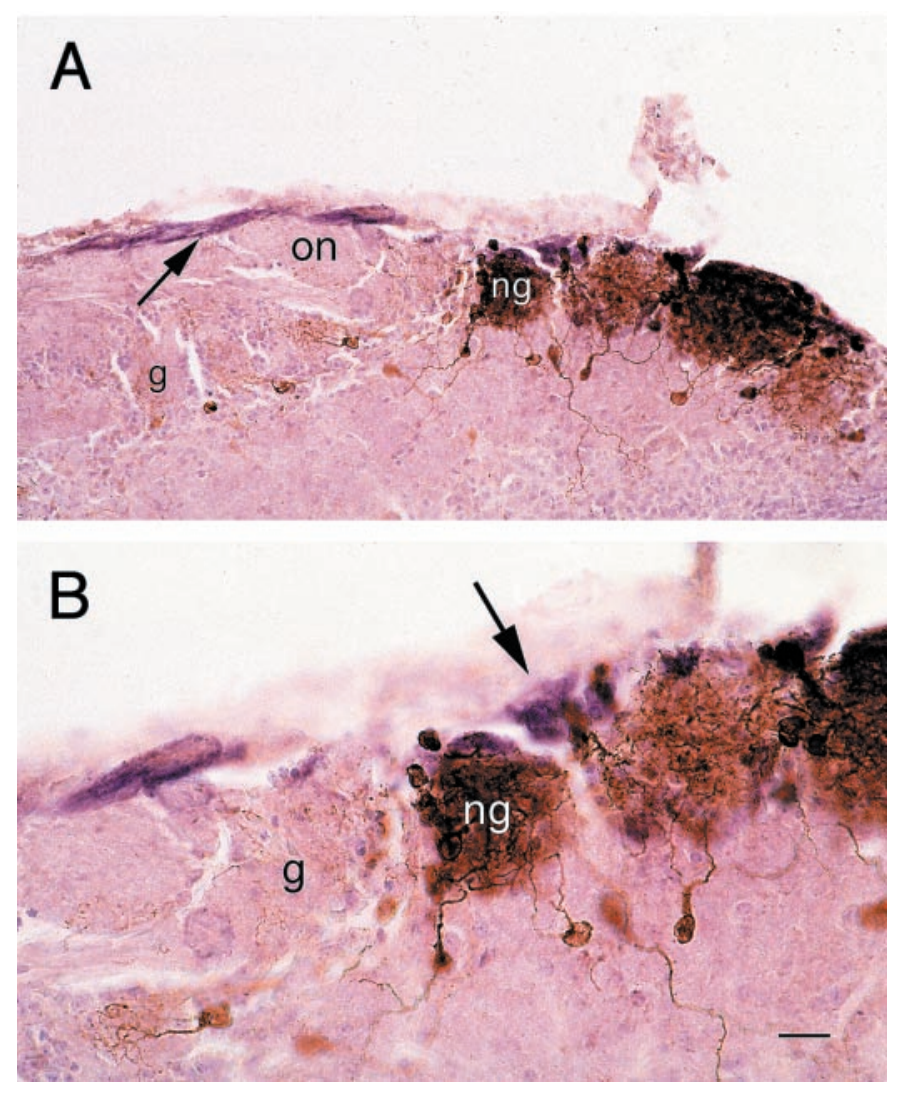

Figure 10. Low-power $(A)$ and high-power $(B)$ photomicrographs illustrating that only the necklace glomeruli $(n g)$ that display intense $\mathrm{TH}$ immunoreactivity are innervated by PDE fibers. Most glomeruli $(g)$ show no tyrosine hydroxylase immunoreactivity (brown) and are not innervated by PDE2-immunoreactive fibers (purple). The PDE2 fibers ( $A$, arrow) course along the edge of the olfactory nerve layer (on) and innervate only the necklace glomeruli (B, arrow). Scale bar: $A, 40 \mu \mathrm{m} ; B, 20 \mu \mathrm{m}$.

migrating to the olfactory bulb from the subventricular zone (SVZ) through the rostral migratory stream (RMS). Because OCNC1 is also expressed in the CNS, including striatum (Bradley et al., 1997; Parent et al., 1998), and bulb size is reduced in other null phenotypes of the CNS, including nCAM-, dlx- and PAX6-deficient mice (Treloar et al., 1997; Bulfone et al., 1998; Dellovade et al., 1998), the reduced size could result from disruption of migration as a consequence of either odor-induced activity or altered expression of the channel in the forebrain. However, migration of periglomerular and granule cells did occur in the OCNC1-null mice, as evidenced by the presence of PAX6 labeling in both the RMS (data not shown) and olfactory bulb. PAX6 was previously shown to be a marker for cells in the SVZ that populate the olfactory bulb including TH-expressing periglomerular cells (Dellovade et al., 1997). Further studies will be required to determine if granule cell migration is altered in OCNC1-null mice and if so by what mechanism.

Abnormal maturation of receptor cell innervation also occurred in the null mice. OMP, which is found in high concentrations in olfactory receptor cells (Margolis, 1972), was used to demonstrate the afferent innervation to the olfactory bulb. OMPimmunoreactive fibers occurred not only in their characteristic locations in the nerve fiber and glomerular layers but also randomly distributed in the external plexiform layer (EPL). Previously, aberrant olfactory receptor afferent fibers were described during development but generally exhibited more organization with distinct bundles in the EPL and a laminar profile in the mitral cell layer (Monti Graziadei et al., 1980; Baker and Farbman, 1993; Gong and Shipley, 1995). The fact that in animals odor-deprived as neonates aberrant fibers are not observed suggests that mechanisms acting prenatally are important to axon guidance and targeting in the null mice. OMP levels were reduced by $64 \%$ in the olfactory bulbs of the null mice, which was consistent with the smaller size of the bulbs. The receptor epithelium in the null mice was $\sim 15 \%$ thinner compared to controls reflecting the decreased level of OMP immunoreactivity in the olfactory bulb. This reduction confirms the previously observed decrease in OMP message (Parent et al., 1998). In addition to the decline in the number of mature receptor cells stained with OMP, there appeared to be fewer immature neurons as reflected by GAP43 immunostaining, suggesting altered generation and maturation of receptor cells in OCNC1-null mice (Verhaagen et al., 1989, 1990).

Transduction of odorant information in OCNC1-null mice may be restricted to a specific subset of receptor cells in the posterior recesses of the olfactory epithelium that innervate glomeruli localized to posterior aspects of the olfactory bulb (Juilfs et al., 1997). These atypical, modified, or necklace glomeruli were previously distinguished by several criteria. Studies using 2-deoxyglucose as an indicator of activity suggested that they were involved in suckling behavior (Teicher et al., 1980; Greer et al., 1982). The glomeruli also were characterized on the basis of high expression of acetyl cholinesterase, choline acetyltransferase (Zheng et al., 1987; Le Jeune and Jourdan, 1991), placental antigen X-P2 (Shinoda et al., 1990), and immunoreactivities to monoclonal antibodies 2C6 and 213 (Ring et al., 1997). They also receive innervation from receptor cells that express a specific guanylyl cyclase (GC-D) and a phosphodiesterase, PDE2 (Juilfs et al., 1997). In contrast, the vast majority of receptor neurons contain a calcium-calmodulin-dependent PDE (PDE1C2) and a high-affinity cAMP-specific PDE (PDE4A) (Juilfs et al., 1997).

The current studies support the hypothesis that these unique glomeruli are innervated by a subset of receptor cells that may contain other channels. Previous studies demonstrated that expression of the catecholamine biosynthetic enzyme TH, expressed in dopamine neurons in the olfactory bulb, is reduced dramatically by odor deprivation (Baker et al., 1983, 1984, 1993; Kosaka et al., 1987; Guthrie et al., 1990; Baker, 1990). Adult OCNC1-null mice had fewer TH-immunoreactive periglomerular cells in most glomeruli, consistent with the inability of receptor cells that lack OCNC1 to respond to odors. However, the necklace glomeruli, identified by their PDE2 innervation, continued to express $\mathrm{TH}$, suggesting that odor-induced stimulation still occurred in the receptor cells projecting to these regions of the olfactory bulb. In view of the expression of OCNC1 in other brain regions, including striatum (Bradley et al., 1997; Parent et al., 1998), the lower levels of TH expression in null mice could be secondary to deficiency of the channel in the CNS and not the receptor epithelium. However, TH activity levels were normal in the substantia nigra and caudate nucleus, the cell body, and target regions of the major midbrain dopaminergic pathway, indicating that the TH loss in the olfactory bulbs of the null mice was likely mediated by odor deprivation. The distribution of cFos expression further supports a relationship between receptor cell activity and the loss of $\mathrm{TH}$ immunoreactivity. As previously found in odor deprivation (Jin et al., 1996), parallel cFos and TH expression could be demonstrated, with most glomeruli containing little 
or no cFos immunoreactivity, whereas the atypical glomeruli express normal levels of cFos labeling.

In summary, these studies demonstrate that OCNC1 is required for normal development of the olfactory bulb, including olfactory bulb size, innervation, and dopamine phenotype. Similarly, the olfactory epithelium does not develop its normal complement of either mature or immature neurons. Most intriguing is the finding that one population of bulbar target neurons, those associated with the atypical or necklace glomeruli, does retain normal expression of the dopamine phenotype, as evidenced by TH staining. The periglomerular neurons in these glomeruli receive their innervation from receptor cells that express a phosphodiesterase and a guanyl cyclase not found in the majority of receptor cells. Therefore, our observations argue that the PDE/ GC-D-expressing receptor cells transduce odor information by a mechanism that is not dependent on OCNC1.

\section{REFERENCES}

Baker H (1990) Unilateral, neonatal olfactory deprivation alters tyrosine hydroxylase expression but not aromatic amino acid decarboxylase or GABA immunoreactivity. Neuroscience 36:761-771.

Baker H, Farbman AI (1993) Olfactory afferent regulation of the dopamine phenotype in the fetal rat olfactory system. Neuroscience 52:115-134.

Baker H, Kawano T, Margolis FL, Joh TH (1983) Transneuronal regulation of tyrosine hydroxylase expression in olfactory bulb of mouse and rat. J Neurosci 3:69-78.

Baker H, Kawano T, Albert VR, Joh TH, Reis DJ, Margolis FL (1984) Olfactory bulb dopamine neurons survive deafferentiation induced loss of tyrosine hydroxylase. Neuroscience 11:605-615.

Baker H, Morel K, Stone DM, Maruniak JA (1993) Adult naris closure profoundly reduces tyrosine hydroxylase expression in mouse olfactory bulb. Brain Res 614:109-116.

Boekhoff I, Tareilus E, Strotmann J, Breer H (1990) Rapid activation of alternative second messenger pathways in olfactory cilia from rats by different odorants. EMBO J 9:2453-2458.

Bönigk W, Bradley J, Müller F, Sesti F, Boekhoff I, Ronnett GV, Kaupp UB, Frings S (1999) The native rat olfactory cyclic nucleotide-gated channel is composed of three distinct subunits. J Neurosci 19:5332-5347.

Bradley J, Li J, Davidson N, Lester HS, Zinn K (1994) Heteromeric olfactory cyclic nucleotide-gated channels: a subunit that confers increased sensitivity to cAMP. Proc Natl Acad Sci USA 91:8890-8894.

Bradley J, Zhang Y, Baskin R, Lester HA, Ronnett GV, Zinn K (1997) Functional expression of the heteromeric "olfactory" cyclic nucleotidegated channel in the hippocampus: a potential effector of synaptic plasticity in brain neurons. J Neurosci 17:1993-2005.

Breer H, Boekhoff I, Tareilus E (1990) Rapid kinetics of second messenger formation in olfactory transduction. Nature 345:65-68.

Brunet LJ, Gold GH, Ngai J (1996) General anosmia caused by a targeted disruption of the mouse olfactory cyclic nucleotide-gated cation channel. Neuron 17:681-693.

Buck L, Axel R (1991) A novel multigene family may encode odorant receptors: a molecular basis for odor recognition. Cell 65:175-187.

Bulfone A, Wang F, Hevner R, Anderson S, Cutforth T, Chen S, Meneses J, Pedersen R, Axel R, Rubenstein JL (1998) An olfactory sensory map develops in the absence of normal projection neurons or GABAergic interneurons. Neuron 21:1273-1282.

Cho JY, Min N, Franzen L, Baker H (1996) Rapid down-regulation of tyrosine hydroxylase expression in the olfactory bulb of naris-occluded adult rats. J Comp Neurol 369:264-276.

Dellovade TL, Pfaff DW, Schwanzel-Fukuda M (1997) Olfactory bulb precursor cell proliferation, migration and survival in small-eye (sey) mice. Soc Neurosci Abstr 23:869.

Dellovade TL, Pfaff DW, Schwanzel-Fukuda M (1998) Olfactory bulb development is altered in small-eye (sey) mice. J Comp Neurol 402:402-418.

Dhallan RS, Yau KW, Schrader KA, Reed RR (1990) Primary structure and functional expression of a cyclic nucleotide-activated channel from olfactory neurons. Nature 347:184-187.
Frazier LI, Brunjes PC (1988) Unilateral odor deprivation: early postnatal changes in olfactory bulb cell density and number. J Comp Neurol 269:355-370.

Gold GH (1999) Controversial issues in vertebrate olfactory transduction. Annu Rev Physiol 61:857-871.

Gong Q, Shipley MT (1995) Evidence that pioneer olfactory axons regulate telencephalon cell cycle kinetics to induce the formation of the olfactory bulb. Neuron 14:91-101.

Greer CA, Stewart WB, Teicher MH, Shepherd GM (1982) Functional development of the olfactory bulb and a unique glomerular complex in the neonatal rat. J Neurosci 2:1744-1759.

Guthrie KM, Gall CM (1995) Odors increase Fos in olfactory bulb neurons including dopaminergic cells. NeuroReport 6:2145-2149.

Guthrie KM, Wilson DA, Leon M (1990) Early unilateral deprivation modifies olfactory bulb function. J Neurosci 10:3402-3412.

Jin BK, Franzen L, Baker H (1996) Regulation of c-Fos mRNA and fos protein expression in olfactory bulbs from unilaterally odor-deprived adult mice. Int J Dev Neurosci 14:971-982.

Joh TH, Geghman C, Reis DJ (1973) Immunochemical demonstration of increased accumulation of TH protein in sympathetic ganglia and adrenal medulla elicited by reserpine. J Neurochem 39:342-348.

Jones DT, Reed RR (1989) $\mathrm{G}_{\text {olf }}$ : An olfactory neuron specific-G protein involved in odorant signal transduction. Science 244:790-795.

Juilfs DM, Fulle HJ, Zhao AZ, Houslay MD, Garbers DL, Beavo JA (1997) A subset of olfactory neurons that selectively express cGMPstimulated phosphodiesterase (PDE2) and guanylyl cyclase-D define a unique olfactory signal transduction pathway. Proc Natl Acad Sci USA 94:3388-3395.

Kawano T, Margolis FL (1982) Transsynaptic regulation of olfactory bulb catecholamines in mice and rats. J Neurochem 39:342-348.

Keller A, Margolis FL (1975) Immunological studies of the rat olfactory marker protein. J Neurochem 24:1101-1106.

Kosaka T, Kosaka K, Hama K, Wu J-W, Nagatsu I (1987) Differential effect of functional olfactory deprivation on the GABAergic and catecholaminergic traits in the rat main olfactory bulb. Brain Res 413:197-203.

Le Jeune H, Jourdan F (1991) Postnatal development of cholinergic markers in the rat olfactory bulb: a histochemical and immunocytochemical study. J Comp Neurol 314:383-395.

Liman ER, Buck LB (1994) A second subunit of the olfactory cyclic nucleotide-gated channel confers high sensitivity to cAMP. Neuron 13:611-621.

Margolis FL (1972) A brain protein unique to the olfactory bulb. Proc Natl Acad Sci USA 69:1221-1224.

Monti Graziadei GA, Stanley RS, Graziadei PPC (1980) The olfactory marker protein in the olfactory system of the mouse during development. Neuroscience 5:1239-1252.

Nadi NS, Head R, Grillo M, Hempstead J, Granno-Reisfeld N, Margolis FL (1981) Chemical deafferentation of the olfactory bulb; plasticity of the levels of tyrosine hydroxylase, dopamine and norepinephrine. Brain Res 213:365-377.

Parent A, Schrader K, Munger SD, Reed RR, Linden DJ, Ronnett GV (1998) Synaptic transmission and hippocampal long-term potentiation in olfactory cyclic nucleotide-gated channel type 1 null mouse. J Neurophysiol 79:3295-3301.

Pedersen PE, Jastreboff PJ, Stewart WB, Shepherd GM (1986) Mapping of an olfactory receptor population that projects to a specific region in the rat olfactory bulb. J Comp Neurol 250:93-108.

Ring G, Mezza RC, Schwob JE (1997) Immunohistochemical identification of discrete subsets of rat olfactory neurons and the glomeruli that they innervate. J Comp Neurol 388:415-34.

Sautter A, Zong X, Hofmann F, Biel M (1998) An isoform of the rod photoreceptor cyclic nucleotide-gated channel $\beta$ subunit expressed in olfactory neurons. Proc Natl Acad Sci USA 95:4696-4701.

Shinoda K, Shiotani Y, Osawa Y (1989) "Necklace olfactory glomeruli" form unique components of the rat primary olfactory system. J Comp Neurol 284:362-373.

Shinoda K, Yagi H, Osawa Y, Shiotani Y (1990) Involvement of specific placental antigen $\mathrm{X}-\mathrm{P}_{2}$ in rat olfaction: an immunohistochemical study in the olfactory bulb. J Comp Neurol 294:340-344.

Teicher MH, Stewart WB, Kauer JS, Shepherd GM (1980) Suckling pheromone stimulation of a modified glomerular region in the developing rat olfactory bulb revealed by the 2-deoxyglucose method. Brain 
Res 194:530-535.

Treloar H, Tomasiewicz H, Magnuson T, Key B (1997) The central pathway of primary olfactory axons is abnormal in mice lacking the N-CAM-180 isoform. J Neurobiol 32:643-58.

Verhaagen J, Oestreicher AB, Gispen WH, Margolis FL (1989) The expression of the growth associated protein B50/GAP43 in the olfactory system of neonatal and adult rats. J Neurosci 9:683-691.

Verhaagen J, Oestreicher AB, Grillo M, Khew-Goodall YS, Gispen WH, Margolis FL (1990) Neuroplasticity in the olfactory system: differential effects of central and peripheral lesions of the primary olfactory pathway on the expression of B-50/GAP43 and the olfactory marker protein. J Neurosci Res 26:31-44.
Wei J-Y, Roy DS, Leconte L, Barnstable CJ (1998) Molecular and pharmacological analysis of cyclic nucleotide-gated channel function in the central nervous system. Prog Neurobiol 56:37-64.

Zagotta WN, Siegelbaum SA (1996) Structure and function of cyclic nucleotide-gated channels. Annu Rev Neurosci 19:235-263.

Zheng LM, Ravel N, Jourdan F (1987) Topography of centrifugal acetylcholinesterase-positive fibers in the olfactory bulb of the rat: evidence for original projections in atypical glomeruli. Neurosci 23:1083-1093.

Zufall F, Firestein S, Shepherd GM (1994) Cyclic nucleotide-gated ion channels and sensory transduction in olfactory receptor neurons. Annu Rev Biophys Biomol Struct 23:577-607. 